\title{
FORTIFIKASI NaFeEDTA PADA COOKIES UBI JALAR KUNING SEBAGAI PRODUK ALTERNATIF UNTUK MENANGGULANGI ANEMIA DEFISIENSI BESI
}

\section{(Fortification of NaFeEDTA in orange fleshed sweet potato cookies as alternative product for iron deficiency anemia)}

\author{
Salma Shafrina Aulia ${ }^{1 *}$, Ninik Rustanti ${ }^{1}$, Deny Yudi Fitranti ${ }^{1}$ \\ ${ }^{1}$ Program Studi Ilmu Gizi, Fakultas Kedokteran, Universitas Diponegoro, Semarang 50275
}

\begin{abstract}
The aims of the study were to analyze iron content, beta carotene content and organoleptic test of orange fleshed sweet potato cookies which had been fortified with NaFeEDTA. This reaserch used experimental method with one factor completely randomized design of iron with $100 \mathrm{ppm}, 150 \mathrm{ppm}$ and $200 \mathrm{ppm}$ of NaFeEDTA. Analysis of iron content was conducted using Atomic Absorption Spectrophotometry and analysis of beta carotene was conducted by using spectrophotometry. Then, organoleptic test was conducted using hedonic test. The result of iron content in cookies is 27.97 ppm-53.42 ppm while beta caroten is 83.40 ppm-129.72 ppm. Organoleptic test results in terms of color, aroma, and texture, the fortified cookies were as well-liked as the control ones; taste, however, the panel found the fortified cookies more preferable. The highest level of iron content, beta carotene content and organoleptic test were orange fleshed sweet potato cookies fortified with 200 ppm NaFeEDTA.
\end{abstract}

Keywords: beta carotene content, cookies, fortification, iron content

\begin{abstract}
ABSTRAK
Tujuan dari penelitian ini adalah mengetahui kadar besi, kadar beta karoten dan tingkat penerimaan cookies ubi jalar kuning yang telah difortifikasi NaFeEDTA. Penelitian ini meupakan penelitian eksperimen dengan rancangan acak lengkap satu faktor yaitu penambahan NaFeEDTA sebanyak 100 ppm, 150 ppm, dan 200 ppm. Analisis kadar besi menggunakan metode AAS (Atomic Absorption spectrophotometry), uji beta karoten menggunakan metode Spektofotometri dan uji penerimaan menggunakan uji hedonik. Hasil yang didapatkan adalah kadar besi cookies berkisar 27,97 ppm hingga 53,42 ppm dengan kadar besi tertinggi pada cookies dengan penambahan $200 \mathrm{ppm}$ yaitu sebesar $53,42 \mathrm{ppm}$, sedangkan kadar beta karoten cookies berkisar 83,40 ppm hingga 129,72 ppm dengan kadar beta karoten tertinggi pada cookies dengan penambahan $200 \mathrm{ppm}$ yaitu sebesar $129,72 \mathrm{ppm}$. Hasil uji penerimaan pada warna, aroma dan tekstur, cookies perlakuan disukai panelis sebagaimana cookies kontrol sedangkan untuk rasa, cookies perlakuan lebih disukai panelis dibanding cookies kontrol. Kesimpulan penelitian ini adalah kadar besi dan kadar beta karoten tertinggi dengan tingkat penerimaan yang baik terdapat pada cookies ubi jalar kuning dengan penambahan 200 ppm NaFeEDTA.
\end{abstract}

Kata kunci : cookies, fortifikasi, kadar besi, kadar beta karoten

\section{PENDAHULUAN}

Anemia defisiensi zat besi merupakan defisiensi zat gizi yang paling banyak di dunia. Anemia defisiensi besi didefinisikan sebagai anemia karena habisnya cadangan besi dalam jaringan (Osungbade 2012). Di Indonesia, prevalensi anemia pada anak usia $\geq 1$ tahun sebesar $21,7 \%$, pada balita $12-59$ bulan sebesar $28,1 \%$, dan ibu hamil sebesar 37,1\% (Kemenkes 2013). Faktor yang paling memengaruhi terjadinya anemia defisiensi besi adalah asupan besi yang rendah dan penyerapan besi yang kurang optimal (Soleimani \& Abbaszadeh 2011).

\footnotetext{
"Korespondensi: Telp: +6281313524890, Surel: salma_shafrina@apps.ipb.ac.id
} 
Anemia defisiensi besi dapat dicegah melalui fortifikasi besi. Fortifikasi besi terbukti menurunkan angka anemia defisiensi besi di Cina sebanyak $42,9 \%$ setelah diberikan fortifikasi NaFeEDTA pada tepung terigu dengan dosis $20 \mathrm{mg} / \mathrm{kg}$ selama dua bulan (Sun et al. 2007). Sodium Iron Etilen Diamin Tetraacetic Acid (NaFeEDTA) adalah jenis fortifikan yang digunakan karena bioavaibilitasnya 2-3 kali lebih tinggi dari besi sulfat \& besi fumarat (Sun et al. 2007). Hal ini dikarenakan NaFeEDTA mengandung kelat yang dapat menghambat reaksi besi dengan fitat pada bahan pangan (Hurrell at al. 2000). Selain itu, NaFeEDTA merupakan fortifikan yang stabil, mempunyai masa simpan lama dan tidak menghambat bioavailabilitas zat gizi lain (WHO 2006).

Cookies adalah salah satu jenis camilan atau makanan ringan yang disukai oleh sebagian besar masyarakat dari balita hingga dewasa. Konsumsi rata-rata cookies di Indonesia adalah $0,40 \mathrm{~kg} / \mathrm{tahun}$ (Suarni 2009). Terdapat beberapa produk makanan komersil yang menambahkan beberapa zat gizi mikro di dalamnya (Tsikritzi et al. 2013). Produk fortifikasi besi yang banyak digunakan adalah tepung terigu dengan komposisi zat besi sebanyak 50 ppm sehingga perlu dikembangkan cookies dengan kandungan besi yang tinggi (Mohammadi et al. 2011). Belum terdapat produk cookies berbahan baku lokal Indonesia yang dikembangkan secara luas di pasaran untuk menanggulangi anemia defisiensi besi.

Pemilihan tepung ubi jalar kuning sebagai bahan utama pembuatan cookies karena ubi jalar kuning merupakan bahan pangan yang banyak ditemukan di Indonesia. Selain itu, kandungan beta karoten yang terdapat dalam tepung ubi jalar kuning cukup tinggi yaitu $8,04 \mathrm{mg} / 100 \mathrm{~g}$ tepung (Othman et al. 2015). Ubi jalar kuning mempunyai fitat yang lebih rendah dibanding sereal sehingga meningkatkan bioavaibilitas besi (Christides et al. 2015).

Beta karoten adalah pro-vitamin A yang dikonversi menjadi vitamin A. Vitamin A berperan dalam sintesa ferritin. Apabila tubuh kekurangan vitamin A maka hormon hepsidin akan naik. Hormon hepsidin merupakan hormon yang mengatur keseimbangan besi dalam tubuh. Meningkatnya hormon hepsidin ini akan menghambat pelepasan besi dari jaringan sehingga menyebabkan besi dalam plasma menurun. Apabila hal ini terjadi terus menerus maka dapat menimbulkan anemia defisiensi besi (Arruda et al. 2009).
Selain itu, Beta karoten berperan sebagai kelat untuk mencegah efek penghambatan penyerapan besi oleh fitat dan polifenol (Humans et al. 1997). Serangkaian studi dari Venezuela secara konsisten menunjukkan bahwa beta karoten lebih efektif meningkatkan penyerapan zat besi dari vitamin A karena mempunyai sifat yang lebih stabil pada $\mathrm{pH}$ dalam duodenum (Laelago et al. 2015). Tujuan penelitian ini adalah untuk mengetahui kadar besi, kadar beta karoten dan tingkat penerimaan cookies ubi jalar kuning yang difortifikasi NaFeEDTA.

\section{METODE}

\section{Desain, tempat, dan waktu}

Penelitian ini merupakan penelitian eksperimental dengan rancangan acak lengkap satu faktor yaitu jumlah fortifikan besi yang terdiri atas 3 perlakuan dan 1 kontrol sehingga terdapat 4 perlakuan. Fortifikan besi yang digunakan adalah NaFeEDTA dengan penambahan 100 ppm, 150 ppm dan 200 ppm. Pemilihan dosis tersebut berdasarkan perhitungan bahwa sebuah cookies dengan berat $10 \mathrm{~g}$ dapat mencukupi kebutuhan besi per10 $\mathrm{kg}$ bb, mengacu pada rekomendasi FAO mengenai penggunaan NaFeEDTA yaitu sebesar $0,2 \mathrm{mg} / \mathrm{kg}$ bb dan pertimbangan hasil uji pendahuluan (WHO 2006). Pengulangan dilakukan 3 kali sehingga didapat 12 sampel percobaan. Seluruh penelitian dilakukan di Universitas Diponegoro. Penelitian dilaksanakan di Laboratorium Ilmu Gizi untuk pembuatan produk, Laboratorium Nutrisi dan Pakan Fakultas Peternakan dan Pertanian untuk menguji kadar besi dan kadar beta karoten. Sementara itu untuk uji hedonik dilakukan di gedung kuliah Ilmu Gizi Fakultas Kedokteran. Penelitian dilaksanakan pada bulan September hingga November 2016.

\section{Bahan dan alat}

Bahan utama terdiri dari tepung ubi jalar kuning yang didapatkan dari Pasar Karangkajen Yogyakarta, sedangkan NaFeEDTA $(13,41 \% \mathrm{Fe})$ didapatkan dari Nanjing Yeshun Industry \& International Trading Co. Ltd, China. Bahan lain yang digunakan adalah gula halus, telur, tepung maizena, chocochip, mentega putih, margarin, susu bubuk dan baking soda yang didapatkan di toko kue di kota Semarang. Sementara itu, bahan kimia yang digunakan untuk analisis kadar besi dan kadar beta karoten adalah Aquademin, $\mathrm{HNO}_{3}$, larutan standar $\mathrm{Fe} 0,2,4,6,8,10 \mathrm{ppm}, \mathrm{KOH}$, dan propanol. 
Alat yang digunakan dalam membuat cookies adalah timbangan digital analitik, baskom, pisau, mixer, oven listrik, dan loyang. Sementara itu untuk analisis kadar besi dan kadar beta karoten peralatan yang dibutuhkan adalah timbangan analitik, AAS (Atomic Absorption Spectometry), cawan, tungku, botol polyethylene, gelas ukur, vortex, tanur, labu ukur, water bath, gelas ukur, dan spektofotometer. Untuk uji hedonik dibutuhkan plastik klip, gelas minum dan kuesioner.

\section{Tahapan penelitian}

Pembuatan produk. Prosedur pembuatan cookies ini yaitu mencampurkan mentega putih $15,43 \%$, margarin $11,57 \%$ dan gula halus $27 \%$ kemudian diaduk menggunakan mixer. Setelah itu, ditambahkan kuning telur $0,66 \%$ dan kembali diaduk hingga homogen. Langkah berikutnya menambahkan tepung ubi jalar kuning sebanyak $33 \%$ yang sudah dicampur dengan NaFeEDTA secara perlahan kemudian ditambahkan dengan susu bubuk $0,41 \%$, tepung maizena $0,2 \%$, vanili dan baking soda $0,01 \%$. Setelah adonan rata, chocochip ditambahkan pada adonan sebanyak $11,71 \%$ dan dicetak dengan berat \pm 10 g per cookies. Setelah itu adonan dipanggang dengan suhu $150^{\circ} \mathrm{C}$ selama 25 menit kemudian dinaikkan suhunya menjadi $180^{\circ} \mathrm{C}$ selama 10 menit dan diturunkan kembali hingga $100^{\circ} \mathrm{C}$ lalu didiamkan selama 10 menit. Setelah itu cookies diletakkan ke dalam wadah kering dan tertutup.

Analisis kandungan gizi. Analisis kadar Fe menggunakan prosedur AOAC dengan alat AAS (Atomic Absorption Spectometry), sementara kadar beta karoten di analisis dengan prosedur AOAC dengan alat spektofotometri (AOAC 2002). Pengujian tersebut dilakukan secara duplo.

Uji organoleptik. Uji organoleptik cookies menggunakan uji hedonik meliputi rasa, warna, aroma, dan tekstur dilakukan pada panelis agak terlatih sebanyak 25 orang mahasiswa Program Studi Ilmu Gizi Universitas Diponegoro. Hasil ukur uji hedonik dikategorikan menjadi skala 1 sampai 4 , yaitu $1=$ sangat tidak suka, $2=$ tidak suka, $3=$ suka, $4=$ sangat suka. Nilai rata-rata yang diperoleh kemudian dikategorikan, yaitu $<1,51$ termasuk sangat tidak suka, 1,51-2,5 termasuk tidak suka, 2,51-3,49 termasuk suka, dan >3,49 termasuk sangat suka.

\section{Pengolahan dan analisis data}

Analisis data menggunakan software SPSS 16.0. Sebelum dianalisis semua data diuji kenormalannya menggunakan uji Shapiro-Wilk karena jumlah sampel $<30$. Hasil analisis kadar besi dan kadar beta karoten diolah menggunakan uji statistik One Way Anova karena data berdistribusi normal dilanjutkan dengan uji post hoc Duncan untuk mengetahui beda nyata kadar besi antar kelompok perlakuan dan kontrol. Data uji organoleptik diuji statistik dengan menggunakan uji Friedman dan dilanjutkan dengan uji Wilcoxon untuk mengetahui beda nyata antar kontrol dan perlakuan.

\section{HASIL DAN PEMBAHASAN}

\section{Kadar besi dan kadar beta karoten pada ba- han baku pembuatan cookies}

Tabel 1 menunjukkan bahwa kandungan besi terbanyak pada kuning telur $(66,63 \mathrm{ppm})$ dan beta karoten terbanyak terdapat pada tepung ubi jalar kuning $(70,88)$, sedangkan kadar besi dan beta karoten paling sedikit terdapat pada tepung maizena $(3,83 \mathrm{ppm}$ dan $0 \mathrm{ppm})$. Dalam formula untuk satu cookies, kontribusi bahan yang mengandung paling banyak besi dan beta karoten adalah tepung ubi jalar kuning $(136,50 \mathrm{ppm}$ besi dan 236.03 ppm beta karoten).

Tabel 1. Kadar besi dan beta karoten bahan baku

\begin{tabular}{lcccc}
\hline \multicolumn{1}{c}{ Bahan baku } & $\begin{array}{c}\text { Kadar besi } \\
(\mathrm{ppm})\end{array}$ & $\begin{array}{c}\text { Kadar beta karoten } \\
(\mathrm{ppm})\end{array}$ & $\begin{array}{c}\text { Kadar besi dalam } \\
\text { formula cookies } \\
(\mathrm{ppm})\end{array}$ & $\begin{array}{c}\text { Kadar beta karoten } \\
\text { dalam formula } \\
\text { cookies }(\mathrm{ppm})\end{array}$ \\
\hline Tepung ubi jalar kuning & 40,99 & 70,88 & 136,50 & 236,03 \\
Tepung maizena & 3,83 & 0,00 & 0,08 & 0,00 \\
Susu bubuk & 17,24 & 55,62 & 0,71 & 2,28 \\
Margarin & 56,23 & 16,12 & 65,06 & 18,65 \\
Mentega & 25,76 & 2,90 & 39,75 & 4,47 \\
Kuning telur & 66,63 & 45,12 & 4,40 & 2,98 \\
\hline
\end{tabular}




\section{Kadar besi dan kadar betakaroten}

Tabel 2. menunjukkan terdapat perbedaan kadar besi pada cookies kontrol dengan kadar besi pada cookies perlakuan. Kadar besi tertinggi terdapat pada cookies ubi jalar kuning yang difortifikasi NaFeEDTA sebesar 200 ppm per cookies. Namun dapat dilihat pula, semakin banyak besi yang ditambahkan maka semakin banyak iron loss yang terjadi. Hasil dari uji statistik $(\mathrm{p}=0,000)$ menunjukkan bahwa semakin banyak NaFeEDTA yang ditambahkan maka semakin banyak kandungan besi di dalam cookies sedangkan dari uji beda antar pelakuan dapat dilihat bahwa tidak ada beda nyata antar perlakuan.

Dari Tabel 2 juga dapat dilihat bahwa tidak ada perbedaan kadar beta karoten antara cookies kontrol dengan cookies perlakuan namun terdapat penurunan beta karoten pada cookies ubi jalar kuning yang difortifikasi 100 ppm dan 150 ppm NaFeEDTA. Hasil dari uji statistik $(\mathrm{p}=0,057)$ menunjukkan bahwa tidak terdapat pengaruh secara bermakna banyaknya NaFeEDTA yang ditambahkan ke dalam cookies.

Berdasarkan data penelitian dapat disimpulkan bahwa terjadi peningkatan kadar besi pada cookies ubi jalar kuning yang diberi penambahan NaFeEDTA $(p=0,000)$, namun dapat dilihat pula bahwa tidak terdapat perbedaan antar cookies perlakuan. Semakin banyak dosis yang ditambahkan kandungan besi dalam cookies semakin meningkat. Hal ini sejalan dengan penelitian Helmyati et al. (2013) bahwa semakin banyak NaFeEDTA yang ditambahkan pada keripik singkong maka kadar besi pada keripik meningkat.

Berdasarkan Tabel 2, dapat dilihat bahwa cookies kontrol mengandung zat besi sebesar $27,97 \mathrm{ppm}$. Hal ini membuktikan bahwa kadar besi dalam cookies dipengaruhi oleh bahan baku pembuatan cookies. Tepung ubi jalar kuning merupakan bahan baku yang menyumbang zat besi tertinggi pada cookies yaitu sebanyak 31,4\%. Pada penelitian ini terjadi penurunan kadar besi berkisar antara 3,98\% hingga 29,44\% dengan iron loss paling sedikit terdapat pada cookies dengan penambahan 100 ppm NaFeEDTA. Hal ini menunjukkan bahwa penambahan $100 \mathrm{ppm}$ NaFeEDTA lebih efektif dibanding dengan cookies perlakuan lainnya. Penurunan besi ini sejalan dengan penelitian Mohammadi et al. (2011) yang menyatakan bahwa penurunan kandungan besi disebabkan karena proses pengolahan seperti pencampuran bahan dan pemanggangan adonan. Proses pemanggangan memengaruhi hasil fortifikasi. Pada penelitian fortifikasi NaFeEDTA pada biskuit dengan dosis $720 \mathrm{mg} / \mathrm{kg}$ NaFeEDTA (9 mg besi per $100 \mathrm{~g}$ ) hanya menurunkan kadar besi sebanyak $0,33 \%$ serta tidak terlalu berpengaruh pada organoleptik (Mohammadi et al. 2011). Sementara itu, kadar besi menurun dari 50 ppm menjadi 29,37 ppm pada fortifikasi NaFeEDTA pada chip dari tepung singkong (Helmyati et al. 2013).

Kadar besi dalam cookies jika dibandingkan dengan produk yang berada di pasaran, lebih tinggi dibanding dengan tepung terigu yang difortifikasi besi yaitu lebih dari $50 \mathrm{mg} / \mathrm{kg}$ dan sesuai dengan Standar Nasional Indonesia (SNI) No. 3751 tahun 2009 sehingga memenuhi syarat minimal zat besi sesuai SNI.

Hasil penelitian menunjukkan bahwa tidak terdapat pengaruh fortifikasi NaFeEDTA terhadap kadar beta karoten. Beta karoten yang terkandung dalam cookies ubi jalar kuning ini cukup tinggi berkisar 83,40 ppm hingga 129,72 ppm. Bahan baku cookies yang memberikan persentase beta karoten tertinggi adalah tepung ubi jalar kuning yaitu sebanyak 75,9\%. Bahan baku tepung ubi jalar kuning ini sangat berpengaruh pada kadar beta karoten cookies. Hal ini sejalan dengan penelitian mengenai crackers yang diberi substitusi tepung ubi jalar kuning mempu-

Tabel 2. Kadar besi dan kadar betakaroten Cookies

\begin{tabular}{ccccccc}
\hline $\begin{array}{c}\text { Penambahan } \\
\text { NaFeEDTA } \\
(\mathrm{ppm})\end{array}$ & $\begin{array}{c}\text { Kadar besi } \\
\text { cookies } \\
(\mathrm{ppm})^{1}\end{array}$ & $\begin{array}{c}\text { Kadar besi dengan } \\
\text { perhitungan } \\
(\mathrm{ppm})\end{array}$ & $\begin{array}{c}\text { Iron } \\
\text { loss } \\
(\%)\end{array}$ & $\begin{array}{c}\text { Kadar beta } \\
\text { karoten }(\mathrm{ppm})^{1}\end{array}$ & $\begin{array}{c}\text { Kadar beta karoten } \\
\text { dengan perhitungan } \\
(\mathrm{ppm})\end{array}$ & $\begin{array}{c}\text { Beta } \\
\text { carotene } \\
\text { loss }(\%)\end{array}$ \\
\hline 0 & $27,97 \pm 1,06^{\mathrm{b}}$ & 39,64 & 29,44 & $121,89 \pm 31,22$ & 142.39 & 20,5 \\
100 & $50,94 \pm 1,48^{\mathrm{a}}$ & 53,05 & 3,98 & $86,43 \pm 14,89$ & 142,39 & 55,96 \\
150 & $51,20 \pm 2,65^{\text {a }}$ & 59,75 & 14,32 & $83,40 \pm 19,47$ & 142,39 & 58,99 \\
200 & $53,42 \pm 2,43^{\mathrm{a}}$ & 66,46 & 19,61 & $129,72 \pm 14,22$ & 142,39 & 12,67 \\
\hline \multicolumn{7}{c}{$\mathrm{p}=0,057$} \\
\hline
\end{tabular}

Keterangan: Angka yang diikuti huruf superscript berbeda (a,b,c,d) menunjukkan beda nyata, ${ }^{1}$ uji One way Anova 
nyai kadar beta karoten sebanyak $82,67 \mu \mathrm{g}$ lebih tinggi dari crackers tanpa substitusi (Aisyiyah 2012). Penelitian lain pada biskuit dengan substitusi tepung ubi jalar kuning juga mempunyai kadar beta karoten 5,47 $\mu \mathrm{g}$ lebih tinggi dibanding kontrol (Afework et al. 2016).

Penelitian ini menunjukkan bahwa terdapat penurunan beta karoten berkisar $12,67 \%$ hingga $58,99 \%$. Hal ini dikarenakan beta karoten merupakan zat gizi yang rentan terhadap degradasi setelah terpapar panas, cahaya dan oksigen (Eldahshan \& Singab 2013; Maramag et al. 2010).

Pemanggangan dilakukan selama 45 menit dengan suhu yang berbeda-beda yaitu $150^{\circ}$ $\mathrm{C}$ pada 25 menit pertama kemudian dinaikkan menjadi $180^{\circ} \mathrm{C}$ selama 10 menit dan diturunkan kembali pada suhu $100^{\circ} \mathrm{C}$ selama 10 menit. Lamanya waktu pemanggangan dan perubahan suhu yang dilakukan bertujuan untuk membuat tekstur cookies menjadi renyah. Pada penelitian lain, kandungan beta karoten dapat berkurang hingga $87 \%$ ketika terjadi proses pemanggangan selama $180^{\circ}$ dalam waktu 45 menit pada ubi jalar kuning (Kotíková et al. 2016).

Penelitian sebelumnya pada biskuit substitusi tepung ubi jalar kuning menunjukkan bahwa waktu pemanggangan tidak terlalu menyebabkan degradasi beta karoten apabila suhu yang digunakan tidak terlalu tinggi (Afework et al. 2016). Adanya fluktuasi beta karoten pada penelitian ini diperkirakan karena metode analisa beta karoten yang dilakukan menggunakan metode spektrofotometri dimana pada metode ini kadar betakaroten ditentukan berdasarkan aktivitas serapan molekul beta karoten terhadap sinar pada panjang gelombang tertentu (Davis et al. 2009). Penambahan besi pada cookies kemungkinan memengaruhi kadar beta karoten yang dihasilkan. Paparan oksigen, panas dan lama waktu pengujian antar sampel dapat memengaruhi hasil pengujian.

\section{Uji organoleptik}

Tingkat penerimaan suatu produk dipengaruhi oleh karakteristik produk. Karakteristik produk terdiri dari sifat fisik, kandungan gizi dan sifat organoleptik produk (Yuni 2016). Tabel 3 menunjukkan hasil uji hedonik dan dapat dilihat bahwa kadar NaFeEDTA berpengaruh nyata terhadap warna $(p=0,037)$ dan rasa $(p=0,000)$ cookies ubi jalar kuning.

Warna Cookies dengan penambahan 100 ppm dan 200 ppm NaFeEDTA memperoleh nilai tertinggi dibanding cookies lainnya meskipun semua cookies dalam kriteria disukai oleh panelis. Apabila dilihat dari segi rasa, terdapat perbedaan tingkat penerimaan rasa pada cookies kontrol dengan cookies perlakuan. Cookies perlakuan lebih disukai oleh panelis dibanding cookies kontrol.

Tabel 3 juga menunjukkan tidak terdapat pengaruh yang signifikan kadar NaFeEDTA terhadap aroma $(\mathrm{p}=0,130)$ dan tekstur $(\mathrm{p}=0,091)$ cookies ubi jalar kuning. Semua aroma dan tekstur cookies baik cookies kontrol maupun cookies perlakuan sama-sama disukai oleh panelis. Secara keseluruhan, cookies yang difortifikasi disukai panelis dengan kisaran nilai 2,72-3,32.

Warna adalah faktor yang menentukan dalam penilaian kualitas makanan dan sangat memengaruhi nilai sensorik secara subjektif. Warna dan tekstur adalah parameter penting yang perlu diperhatikan selama proses pembuatan cookies (Lara et al. 2011). NaFeEDTA memang memberikan perubahan warna pada cookies menjadi warna kecokelatan sehingga terlihat lebih menarik. Hal ini menunjukkan

Tabel 3. Hasil uji hedonik terhadap rasa, aroma dan tekstur cookies

\begin{tabular}{ccccc}
\hline $\begin{array}{c}\text { Penambahan } \\
\text { NaFeEDTA }(\mathrm{ppm})\end{array}$ & Warna $^{1}$ & Rasa $^{1}$ & Aroma $^{1}$ & Tekstur $^{1}$ \\
\hline \multirow{2}{*}{0} & $2,60 \pm 0,76^{\mathrm{a}}$ & $2,36 \pm 0,64^{\mathrm{a}}$ & $2,52 \pm 0,82$ & $2,76 \pm 0,72$ \\
& Suka & Tidak suka & Suka & Suka \\
\multirow{2}{*}{100} & $3,12 \pm 0,73^{\mathrm{b}}$ & $3,32 \pm 0,85^{\mathrm{b}}$ & $2,72 \pm 0,94$ & $3,08 \pm 0,76$ \\
& Suka & Suka & Suka & Suka \\
\multirow{2}{*}{150} & $3,08 \pm 0,70^{\mathrm{b}}$ & $2,88 \pm 0,78^{\mathrm{b}}$ & $2,76 \pm 0,78$ & $3,12 \pm 0,53$ \\
& Suka & Suka & Suka & Suka \\
200 & $3,12 \pm 0,67^{\mathrm{b}}$ & $3,00 \pm 0,50^{\mathrm{b}}$ & $2,88 \pm 0,73$ & $2,84 \pm 0,55$ \\
& Suka & Suka & Suka & Suka \\
\hline & $\mathrm{p}=0,037$ & $\mathrm{p}=0,000$ & $\mathrm{p}=0,130$ & $\mathrm{p}=0,091$ \\
\hline
\end{tabular}


bahwa penambahan NaFeEDTA tidak berpengaruh pada kesukaan panelis terhadap warna cookies (WHO 2006). Hal ini sejalan dengan penelitian sebelumnya pada biskuit dengan fortifikasi NaFeEDTA yang menunjukkan bahwa NaFeEDTA membuat perubahan warna pada biskuit yaitu menimbulkan warna kecokelatan (Mohammadi et al. 2011).

Parameter rasa pada produk menunjukkan bahwa cookies kontrol tidak disukai oleh panelis sedangkan cookies perlakuan disukai oleh panelis. Cookies kontrol memiliki citarasa khas ubi jalar kuning yang kuat karena mengandung senyawa terpenoid sehingga panelis kurang menyukai cookies kontrol (Septianingrum 2009). Penggunaan NaFeEDTA yang memberikan aftertaste dapat menutupi citarasa ubi kuning tersebut sehingga cookies perlakuan disukai panelis.

Hasil uji pada parameter aroma menunjukkan bahwa kadar NaFeEDTA yang ditambahkan tidak berpengaruh terhadap aroma cookies. Hal ini dikarenakan mineral yang digunakan dalam jumlah sedikit sehingga tidak memengaruhi aroma dari produk (Nkhata et al. 2013).

Tekstur terbaik dimiliki oleh cookies dengan penambahan NaFeEDTA 150 ppm. Menurut hasil uji organoleptik diketahui bahwa pada cookies kontrol dan cookies perlakuan disukai oleh panelis. Tidak ada pengaruh kadar NaFeEDTA terhadap tekstur cookies ubi jalar kuning $(\mathrm{p}=0,091)$. Tekstur pada cookies dipengaruhi oleh bahan baku cookies seperti tepung, telur dan susu. Pemanggangan berpengaruh pada tekstur cookies. Pemanggangan juga menyebabkan perubahan fisik dan biokimia. Hal ini bisa berupa penguapan, peningkatan volume, struktur berpori dan pembentukan kerak (Lara et al. 2011; Baldino et al. 2014).

Hasil penelitian secara keseluruhan disimpulkan bahwa kadar besi dan kadar beta karoten tertinggi terdapat pada cookies dengan penambahan 200 ppm NaFeEDTA namun untuk hasil fortifikasi yang paling efektif terdapat pada cookies dengan penambahan 100 ppm NaFeEDTA karena memiliki iron loss terendah. Untuk hasil organoleptik, semua cookies yang difortifikasi disukai oleh panelis. Dari hasil perhitungan, konsumsi lima keping cookies dengan fortifikasi 200 ppm dapat menyumbangkan asupan besi sebanyak 2,67 mg besi dan 6,49 mg beta karoten.

\section{KESIMPULAN}

Terdapat pengaruh signifikan fortifikasi NaFeEDTA terhadap kadar besi pada cookies ubi jalar kuning dengan kadar besi terbaik pada cookies dengan penambahan 200 ppm NaFeEDTA yaitu sebesar 53,42 ppm. Sementara itu, kadar beta karoten tertinggi terdapat pada cookies dengan penambahan $200 \mathrm{ppm}$ NaFeEDTA yaitu sebesar 129,72 ppm. Untuk hasil uji penerimaan pada warna, aroma dan tekstur, cookies perlakuan disukai panelis sebagaimana cookies kontrol sedangkan untuk rasa, cookies perlakuan lebih disukai panelis dibanding cookies kontrol. Perlu dilakukannya penelitian lanjutan untuk mengetahui pengaruh cookies ubi jalar kuning yang difortifikasi NaFeEDTA pada penderita anemia defisiensi besi.

\section{UCAPAN TERIMA KASIH}

Penulis mengucapkan terimakasih kepada PT Indofood Sukses Makmur Tbk yang telah memberikan dana penelitian kepada penulis melalui program Indofood Riset Nugraha tahun 2016.

\section{DAFTAR PUSTAKA}

Afework A, Abegaz K, Mezgebe AG. 2016. Development of pro-vitamin A and energy rich biscuits : Blending of orange-fleshed sweet potato (Ipomea batatas L.) with wheat (Triticum vulgare) flour and altering baking temperature and time. Afr J Food Sci 10(6):79-86.

Aisyiyah LN, Rustanti N. 2012. Kandungan betakaroten, protein, kalsium, dan uji kesukaan crackers dengan substitusi ubi jalar kuning dan ikan teri nasi untuk Anak KVA. Journal of Nutrition Collage 2:145-153.

[AOAC] Association of Official Analytical Chemist. 2002. AOAC Official Method 999.11 Determination of Lead, Cadmium, Copper, Iron, and Zinc in Foods.

Arruda SF, Machado E, Siqueira DA, Valência FF. 2009. Vitamin A deficiency increases hepcidin expression and oxidative stress in rat. Nutrition 25(4):472-478. http://dx.doi. org/10.1016/j.nut.2008.11.030.

Baldino N, Gabriele D, Romana F, Cindio B , Cicerelli L. 2014. Modeling of baking behavior of semi-sweet short dough biscuits. 
Innovative Food Science and Emerging Technologies 25:40-52. http://dx.doi.org /10.1016/ j.ifset.2013.12.022.

Christides T, Amagloh F, Coad J. 2015. Iron Bioavailability and Provitamin A from Sweet Potato- and Cereal-Based Complementary Foods. Foods 4(3): 463-476. http://www. mdpi.com/2304-8158/4/3/463/htm.

Davis AR, Fish WW, Perkins-veazie P. 2009. A Rapid Spectrophotometric Method to Determine $\beta$-Carotene Content in Cucumis melo germplasm. Cucurbit Genetics Cooperative report 7:5-7.

Eldahshan OA, Singab ANB.2013. Carotenoids. Journal of Pharmacognosy and Phytochemistry 2(1):225-234.

Helmyati S, Pamungkas NP, Lestari LA, Hendarta NY. 2013. Sensory and Organoleptic Characteristic, Zinc and Iron Content of Fortified Chips from Cassava Flour. Journal of food science and engineering 3:4754.

Humans C, et al. 1997. Nutrient Requirements and Interactions Vitamin A and b -Carotene Can Improve Nonheme Iron Absorption from. Journal of Nutrition :646-650.

Hurrell RF, Burri J, Cook JD. 2000. An evaluation of EDTA compounds for iron fortification of cereal-based foods. Food Sci Hum Nutr.

[Kemenkes RI] Kementrian Kesehatan Republik Indonesia. 2013. Riset Kesehatan Dasar. Jakarta: Kemenkes RI.

Kotíková Z, Šulc M, Lachman J, Pivec V, Orsák M, Hamouz K. 2016. Carotenoid profile and retention in yellow-, purple- and redfleshed potatoes after thermal processing. Food Chemistry 197:992-1001.

Laelago T, Haile A, Fekadu T. 2015. Production and Quality Evaluation of Cookies Enriched with $\beta$-Carotene by Blending Orange-Fleshed Sweet Potato and Wheat flours for Alleviation of Nutritional Insecurity. International Journal of Food Science and Nutrition Engineering 5(5):209217.

Lara E, Cortés P, Briones V, Perez M. 2011. Structural and physical modi fi cations of corn biscuits during baking process. LWTFood Science and Technology 44(3):622$630 . \quad$ http://dx.doi.org/10.1016/j. lwt.2010.10.007.
Maramag CC, Mercado JD, Solon PR, Solon JAA, Tengcol LW Blumberg JB et al. 2010. Influence of carotene-rich vegetable meals on the prevalence of anaemia and iron deficiency in Filipino schoolchildren. European Journal of Clinical Nutrition 64(5):468-474. http://dx.doi.org/10.1038/ ejen.2010.23.

Mohammadi M, Abedi A, Azizi MH, Ahmadian FS and Hamed P. 2011. Development of fortified biscuit using NaFeEDTA. J Sci Food Agric doi:10.1002/jsfa.4405.

Nkhata SG, Ustunol Z, Menevseoglu A. 2015. Iron fortification of yogurt and pasteurized milk. Food Sci 3(3):1-12. DOI: http:// dx.doi.org/10.15226/jnhfs.2015.00142

Osungbade KO, Oladunjoye AO. 2012. Preventive treatments of iron deficiency anaemia in pregnancy: a review of their effectiveness and implications for health system strengthening. J Pregnancy. doi:10.1155/2012/454601.

Othman R, Kammona S, Jaswir I, Jamal P. 2015. Characterisation of carotenoid content in diverse local sweet potato (Ipomoea batatas) flesh tubers. Int J Pharm Pharm Sci 7: 347-351.

Septianingrum ER. 2009. Identifikasi penyebab dan upaya pengurangan aftertaste pahit pada cookies ubi jalar (Ipomoea batatas l.) dengan karakteristik tekstur menyerupai cookies keladi enny [Skripsi]. Bogor: Institut pertanian bogor.

Soleimani, Abbaszadeh N. 2011. Relationship between anaemia , caused from the iron deficiency, and academic achievement among third grade high school female students. Procedia - Social and Behavioral Sciences 29:1877-1884. http://dx.doi.org/10.1016/j. sbspro.2011.11.437.

Suarni. 2009. Prospek pemanfaatan tepung jagung untuk kue kering. Jurnal Litbang Pertanian 28(274):63-71.

Sun J, Huang J, Wang L, Wang A, Huo J, Chen J, et al. 2007. Effects of wheat flour fortified with different iron fortificants on iron status and anemia prevalence in iron deficient anemic students in Northern China. Asia Pac J Clin Nutr 16:116-121.

Tsikritzi R, Moynihan PJ, Gosney MA, Allenc VJ, Methven L. 2013. The effect of macroand micro-nutrient fortification of biscuits 
Aulia dkk.

on their sensory properties and on hedonic liking of older people. Journal of the Science of Food and Agriculture

Yuni S. 2016. Pengembangan produk yang berpotensi sebagai minuman fungsional untuk penderita prahipertensi. J Gizi Pangan 11(2):135-142.
[WHO] World Health Organization. 2006. Guidelines on food fortification with micronutrients. US:WHO. 